OPEN ACCESS

Edited by:

Sarah J. Spencer,

RMIT University, Australia

Reviewed by:

Tamas Kozicz,

Radboud University

Nijmegen, Netherlands

Chris Scott,

Charles Sturt University,

Australia

*Correspondence:

Renata Frazao

rfrazao@usp.br

Specialty section:

This article was submitted to

Neuroendocrine Science,

a section of the journal

Frontiers in Endocrinology

Received: 10 November 2017 Accepted: 02 February 2018

Published: 20 February 2018

Citation:

Bohlen TM, Silveira MA, Buonfiglio DC, Ferreira-Neto HC, Cipolla-Neto J, Donato J Jr. and

Frazao $R$ (2018) A Short-Day

Photoperiod Delays the Timing of Puberty in Female Mice via Changes

in the Kisspeptin System.

Front. Endocrinol. 9:44. doi: 10.3389/fendo.2018.00044

\section{A Short-Day Photoperiod Delays the Timing of Puberty in Female Mice via Changes in the Kisspeptin System}

\author{
Tabata Mariz Bohlen', Marina Augusto Silveira', Daniella do Carmo Buonfiglio², \\ Hildebrando Candido Ferreira-Neto ${ }^{3}$, José Cipolla-Neto ${ }^{2}$, Jose Donato $\mathrm{Jr}^{2}$ and \\ Renata Frazao ${ }^{1 *}$ \\ ${ }^{1}$ Department of Anatomy, Institute of Biomedical Sciences, University of São Paulo, São Paulo, Brazil, ${ }^{2}$ Department of \\ Physiology and Biophysics, Institute of Biomedical Sciences, University of São Paulo, São Paulo, Brazil, ${ }^{3}$ Department of \\ Physiology, Augusta University, Augusta, GA, United States
}

The reproduction of seasonal breeders is modulated by exposure to light in an interval of $24 \mathrm{~h}$ defined as photoperiod. The interruption of reproductive functions in seasonally breeding rodents is accompanied by the suppression of the Kiss 1 gene expression, which is known to be essential for reproduction. In non-seasonal male rodents, such as rats and mice, short-day photoperiod (SP) conditions or exogenous melatonin treatment also have anti-gonadotropic effects; however, whether photoperiod is able to modulate the puberty onset or Kiss 1 gene expression in mice is unknown. In the present study, we investigated whether photoperiodism influences the sexual maturation of female mice via changes in the kisspeptin system. We observed that SP condition delayed the timing of puberty in female mice, decreased the hypothalamic expression of genes related to the reproductive axis and reduced the number of Kiss1-expressing neurons in the rostral hypothalamus. However, SP also reduced the body weight gain during development and affected the expression of neuropeptides involved in the energy balance regulation. When body weight was recovered via a reduction in litter size, the timing of puberty in mice born and raised in SP was advanced and the effects in hypothalamic mRNA expression were reverted. These results suggest that the SP delays the timing of puberty in female mice via changes in the kisspeptin system, although the effects on hypothalamic-pituitary-gonadal axis are likely secondary to changes in body weight gain.

Keywords: puberty onset, Kiss1, photoperiod, melatonin, energy balance

\section{INTRODUCTION}

Photoperiod duration is one of the most potent environmental cues responsible for synchronizing daily variations in mammalian physiology, including factors that control the reproductive system. The mechanism by which the light/dark cycle synchronizes biological functions in mammals relies on the suprachiasmatic nuclei ( $\mathrm{SCN}$ ), which are considered the master clock that coordinates daily rhythms. SCN neurons receive information about the light/dark cycle via the retino-hypothalamic tract $(1,2)$. The lack of circadian rhythms, as induced by SCN ablation, or free-running rhythms, as induced by constant light, leads to reproductive deficits as demonstrated by impairment of ovulation, disruption of the estrous cycle and LH surge (3-5). Melatonin is the principal hormone produced by the pineal gland; its secretion is modulated by photoperiod duration, depends upon input from the 
$\operatorname{SCN}(6,7)$, and is considered an important factor for the control of reproduction in melatonin-proficient mammals. Accordingly, estrous cyclicity can be reestablished by exogenous melatonin administration in female rats exposed to constant light (5). On the other hand, short-days or exogenous melatonin treatment has been described to induce anti-gonadotropic effects (5, 8-12). Nevertheless, the neuroendocrine mechanisms by which variations in photoperiod modulate the hypothalamus-pituitary-gonadal (HPG) axis are not fully understood.

Interestingly, the hypothalamic Kiss 1 expression is suppressed in winter or by artificial SP in Syrian hamsters, and this effect is prevented by ablation of the pineal gland $(13,14)$. Kisspeptins are encoded by the Kiss 1 gene and are known as the most potent activators of GnRH neurons $(15,16)$. Kisspeptin neurons in rodents are found in the anteroventral periventricular nucleus (AVPV), the rostral periventricular nucleus $(\mathrm{PeN})$, and the arcuate nucleus of the hypothalamus (ARH) $(13,17,18)$. However, whether photoperiod variations are able to directly affect kisspeptin neurons in mice remains unknown.

To investigate whether photoperiodism may influence the sexual maturation and the kisspeptin system of female mice, we bred mice expressing the humanized Renilla green fluorescent protein (hrGFP) under the transcriptional control of the Kiss 1 gene (19) and raised them under a short-day (6 h:18 h light/dark cycle) or a $12 \mathrm{~h}: 12 \mathrm{~h}$ light/dark cycle. We assessed the timing of sexual maturation, and the data obtained were correlated with molecular analyses in the hypothalamus.

\section{MATERIALS AND METHODS}

\section{Animals}

To evaluate the effects of photoperiod on the timing of puberty, we used the Kiss1-hrGFP mouse (C57BL/6-Tg(Kiss1-hrGFP) KG26Cfe/J, Jackson Laboratories) (19). This transgenic mouse model allows the visualization of Kiss1-expressing cells through the hrGFP protein. Mice were weaned at 3 weeks of age and genotyped via PCR using DNA extracted from the tail tip (REDExtract-N-Amp ${ }^{\mathrm{TM}}$ Tissue PCR Kit, Sigma). Kiss1-hrGFP mice were housed in the animal care facility of the Department of Anatomy, Institute of Biomedical Sciences, University of São Paulo, in an environment with controlled light and temperature $\left(23 \pm 2^{\circ} \mathrm{C}\right)$. All experiments and procedures were performed in accordance with the guidelines established by the National Institute of Health's Guide for the Care and Use of Laboratory Animals and were approved by the Committee on the Care and Use of Laboratory Animals of the Institute of Biomedical Sciences, University of São Paulo.

\section{Evaluation of Sexual Maturation}

The timing of puberty was investigated in pups born and raised at a constant $12 \mathrm{~h}: 12 \mathrm{~h}$ light/dark cycle [control, lights on at 06:00 a.m.; Zeitgeber time (ZT) 0] or 6h:18 h light/dark cycle (SP, lights on at 12 p.m.). Kiss1-hrGFP mice were raised and bred in $12 \mathrm{~h}: 12 \mathrm{~h}$ light/dark conditions and their offspring were included in the control group. A group of adult Kiss1-hrGFP mice were transferred to SP conditions at least 15 days before mating for acclimation. Only mice from average-sized litters (6-8 pups per litter) were included in control $(n=12)$ and SP groups $(n=14)$. To determine whether body mass gain would account for the differences in the timing of puberty in female mice born and raised in SP, we induced overnutrition by reducing the litter size to three pups at postnatal day 5, as previously described (20-22). Therefore, females were raised in small litters in SP $(n=13)$, and the obtained data were compared with data from females born and raised in regular litters $(n=16)$ in SP (6-8 pups per litter). Sexual maturation was determined by the age at vaginal opening, assessed through the first occurrence of vaginal cornification in the vaginal lavage (first estrus) and the onset of cyclicity, which is the first occurrence of an estrous cycle of typical duration (4-7 days in mice), as previously described $(22,23)$. These parameters were monitored daily, $1 \mathrm{~h}$ before lights off, until 70 days of age. Body weight was monitored weekly and at each specific stage of sexual maturation. The uterine mass was also determined in adult female mice ( $n=4 / 10$ per group).

\section{Relative Gene Expression}

For gene expression analyses, 10- to 12-week old female mice in diestrus were selected after daily observation of vaginal smears and confirmation of a regular estrous cycle. Mice were sacrificed by decapitation in the morning (ZT2-3 for control group, $n=7$; and ZT20-21 for SP group, regular litter, $n=7$; small litter, $n=9$ ). The hypothalamus was carefully dissected for relative gene expression analysis, according to previously described anatomical references (22). The total RNA from the hypothalamus was extracted with TRIzol Reagent according to the manufacturer's instructions (Thermo Fisher Scientific). An assessment of RNA quantity was performed using an Epoch Microplate Spectrophotometer (BioTek). RNA was incubated in RNase-free DNase I (Roche Applied Science). Reverse transcription was performed with $2 \mu \mathrm{g}$ of total RNA obtained from the hypothalamus with SuperScript II Reverse Transcriptase (Invitrogen) and random primers $\mathrm{p}(\mathrm{dN}) 6$ (Roche Applied Science). Real-time polymerase chain reaction was performed using the 7500 Fast Real-Time PCR System (Applied Biosystems) and Power SYBR Green PCR Master Mix (Applied Biosystems). Specific primers were used for each target gene (Table 1) as previously described (22). Relative mRNA was quantified by calculating $2^{-\Delta \Delta} \mathrm{Ct}$. Data were normalized to the geometric average of housekeeping genes Actb, Gapdh, and Ppia and reported as fold changes compared with values obtained from the control group (set at 1.0).

\section{Brain Histology}

To determine the number of Kiss1-expressing neurons in control $(n=4)$ and SP $(n=4)$ groups, we selected adult female mice in diestrus after daily observation of vaginal smears and confirmation of a regular estrous cycle. Animals were deeply anesthetized in the afternoon (ZT10-11 for control group and ZT4-5 for SP group), and perfused transcardially with saline followed by a $10 \%$ buffered formalin solution, $\mathrm{pH}$ 7.4. The brains were collected, post-fixed overnight at $4^{\circ} \mathrm{C}$, and cryoprotected for $24-48 \mathrm{~h}$ at $4^{\circ} \mathrm{C}$ in $0.1 \mathrm{M}$ phosphate-buffered saline (PBS) containing $20 \%$ sucrose, $\mathrm{pH}$ 7.4. Brains were cut in four series of $30 \mu \mathrm{m}$ sections each in the frontal plane on a freezing microtome and stored at 
TABLE 1 | Primer sequences.

\begin{tabular}{|c|c|c|c|c|}
\hline Gene of interest & Accession no. & Forward primer $\left(5^{\prime}-3^{\prime}\right)$ & Reverse primer $\left(5^{\prime}-3^{\prime}\right)$ & Product size (bp) \\
\hline Actb & NM_007393.5 & AGCCTGGATGGCTACGTACA & ССТCTGAACCCTAAGGCCAA & 90 \\
\hline Agrp & NM_001271806.1 & CTाGGCGGAGGTGCTAGAT & AGGACTCGTGCAGCCTTACAC & 75 \\
\hline Crh & NM_205769.2 & TGGATCTCACCTTCCACCTTCTG & CCGATAATCTCCATCAGTITCCTG & 103 \\
\hline Ppia & NM_008907.1 & TATCTGCACTGCCAAGACTGAGT & CTTCTTGCTGGTCTTGCCATTCC & 128 \\
\hline Esr1 & NM_007956.5 & GCAGATTGGGAGCAGCTGGTTCA & TGGAGATTCAAGTCCCCAAA & 74 \\
\hline Gal & NM_010253 & TGTCGCTAAATGATCTGTGGTTGTC & TGCAACCCTGTCAGCCACTC & 121 \\
\hline Gapdh & NM_001289726.1 & GGCAGCCCAGAACATCAT & CCGTTCAGCTCTGGGATGAC & 75 \\
\hline Gnrh1 & NM_008145.2 & GGCTTCTGCCATITGATCCAC & CCCTITGACTITCACATCC & 200 \\
\hline Kiss1 & NM_178260.3 & GGCAAAAGTGAAGCCTGGAT & GATTCCTITCCCAGGCATT & 75 \\
\hline Npy & NM_023456 & CCCTCAGCCAGAATGCCCAA & CCGCCCGCCATGATGCTAGGTA & 95 \\
\hline Pomc & NM_001278581.1 & GAGGCCACTGAACATCTITGTC & GCAGAGGCAAAACAAGATTGG & 252 \\
\hline Tac2 & NM_001199971 & CCGCTCCATCTCTCTGGAAG & TGCATGTCACGTITCTGTGG & 94 \\
\hline
\end{tabular}

$-20^{\circ} \mathrm{C}$ in cryoprotectant, until they were processed for immunohistochemistry to detect hrGFP-immunoreactivity.

Brain sections were rinsed in $0.02 \mathrm{M}$ potassium PBS (KPBS), $\mathrm{pH} 7.4$, followed by a pretreatment with $0.3 \%$ hydrogen peroxide for $30 \mathrm{~min}$. After rinses in KPBS, the sections were blocked in $3 \%$ normal donkey serum for $1 \mathrm{~h}$, followed by incubation in anti-hrGFP antibody (1:2,000, Stratagene) for $24 \mathrm{~h}$. Subsequently, the sections were incubated with biotin-conjugated donkey antirabbit IgG (1:1,000, Jackson Laboratories) for $1 \mathrm{~h}$ followed by an avidin-biotin complex (1:500, Vector Labs, Burlingame) for $1 \mathrm{~h}$. The peroxidase reaction was performed using $0.05 \% 3,3^{\prime}$-diaminobenzidine and $0.03 \%$ hydrogen peroxide. The sections were mounted onto gelatin-coated slides and coverslipped using DPX mounting medium.

The number of Kiss1-expressing neurons were quantified in two rostrocaudal levels of the AVPV/PeN (relative to bregma: 0.26 and 0.02 ) and two rostrocaudal levels of the ARH (relative to bregma: -1.94 and -2.30 ). The approximate bregma coordinates of each rostrocaudal level were obtained from the mouse brain atlas (24). The cells were counted on one side of a defined level of each nucleus, as previously described (19). The photomicrographs of brain sections were acquired using a Zeiss Axiocam HRc camera connected to a Zeiss AxioImager A1 microscope (Zeiss, Munich, Germany), and the images were digitized using AxioVision software (Zeiss). Photoshop image-editing software was used to combine the photomicrographs into plates. Only the sharpness, contrast and brightness were adjusted.

\section{Statistical Analysis}

Statistical analyses were performed using GraphPad Prism software. The data were expressed as the mean \pm SEM. The comparisons between two groups were performed using the unpaired two-tailed Student's $t$-test. For temporal body weight analyses, we used the two-way ANOVA and the Bonferroni post-test. A $P$ value $<0.05$ was considered statistically significant.

\section{RESULTS}

\section{A Short-Day Photoperiod (SP) Delays the Sexual Maturation of Female Mice}

To evaluate whether SP influences the timing of puberty in a non-seasonal breeder, we assessed the age of vaginal opening, first estrus and onset of estrus cyclicity in female mice. Females raised in SP exhibited a significant delay in the age of vaginal opening (Figures 1A,B; $P=0.0013$ ), first estrus (Figures 1D,E; $P=0.0001$ ) and the onset of estrous cyclicity (Figures $\mathbf{1 G}, \mathbf{H}$; $P<0.0001)$ compared to control female mice. While more than $80 \%$ of control mice had displayed vaginal opening by 33 days of age, only $25 \%$ of females of the SP group had reached the same stage of sexual maturation (Figure 1A). Approximately $80 \%$ of control females had their first estrus by 44 days of age, whereas less than 25\% SP females reached estrus by that age (Figure 1D). In addition, while $100 \%$ of control females had already shown regular estrous cycles by 47 days of age, less than $30 \%$ of females under SP had started to cycle at the same age (Figure 1G). At the age of vaginal opening, female mice raised in SP exhibited similar body weight to control females (Figure 1C; $P=0.39$ ). However, at the ages of first estrus (Figure 1F; $P=0.005$ ) and onset of cornification (Figure 1I; $P=0.01$ ), females under SP exhibited lower body weight compared to controls. Because photoperiodism has been previously shown to influence the body weight of seasonally and non-seasonally breeding rodents $(11,12,25$, 26 ), we evaluated in more detail whether the SP could affect the body weight gain during development. Our findings showed that mice born and raised in SP exhibited a lower body weight gain throughout development (Figure 1J; $P=0.0005$ ). In addition, no significant differences between groups were noted in the uterine mass of adult mice (Figure 1K, $P=0.08$ ).

\section{A SP Modulates the Hypothalamic Expression of Genes Related to the Reproductive Axis and Energy Balance}

Because neurons responsible for coordinating reproductive function and energy balance are distributed in the hypothalamus, we investigated whether the delayed sexual maturation and reduced body weight of animals raised under SP were accompanied by changes in hypothalamic gene expression. We first assessed the expression of genes related to the reproductive axis. Interestingly, adult females raised under SP showed decreased expression of the mRNA encoding the Kiss 1 gene $(P=0.04)$, Tachykinin (Tac2, $P=0.02)$, and Galanin (Gal, $P=0.02)$ and exhibited a trend toward lower expression of mRNA encoding GnRH (Gnrh1, $P=0.06$ ) compared to control mice (Figure 2). No significant changes between groups were 

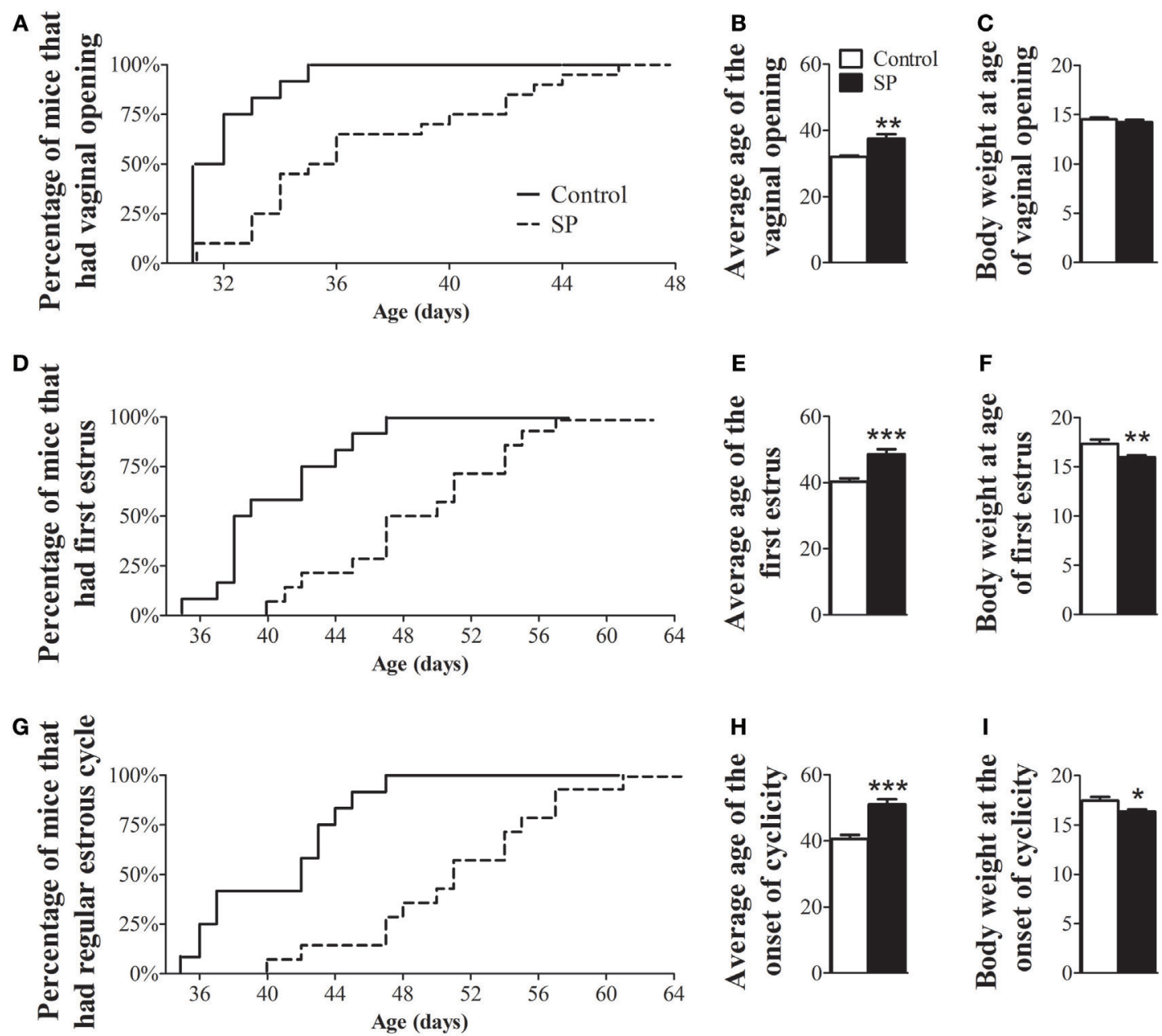

FIGURE 1 | Female mice born and raised under a short-day photoperiod (SP) exhibit delayed sexual maturation. (A,D,G) Graphs showing the percentages of control females and females born and raised under a SP ( $n=12 / 14$ per group) that exhibited vaginal opening (A), first estrus (D), and the first occurrence of an estrous cycle of typical duration (G). (B,E,H) Average time required for control and SP females to exhibit vaginal opening (B), first estrus (E), and the onset of cyclicity (H). (C,F,I,J). Body weight of control and females under SP at specific stages of sexual maturation and throughout development $\mathbf{( J )}$. (K) Uterine mass of adult controls and adult females in SP $\left(n=9 / 10\right.$ per group). ${ }^{\star} P<0.05$, ${ }^{\star \star} P<0.005,{ }^{\star \star \star} P<0.0005$ vs control.

observed in the hypothalamic mRNA encoding the estrogen receptor alpha (Esr1; $P=0.1$ ) (Figure 2). In addition, because females raised under SP were leaner, we also assessed the hypothalamic mRNA expression of neuropeptides involved in the regulation of energy balance, such as agouti-related protein (Agrp), neuropeptide Y (Npy), and pro-opiomelanocortin $($ Pomc). Agrp mRNA expression was significantly decreased in the hypothalamus of females born and raised under SP compared with control females $(P=0.01$; Figure 2$)$. No changes in Npy $(P=0.13)$ or Pomc $(P=0.13)$ mRNA expression were observed. In addition, the expression of corticotropin-releasing hormone $(\mathrm{Crh})$ mRNA, which could indicate a stress-mediated response, was not influenced by the short-day photoperiod $(P=0.5$; Figure 2). 


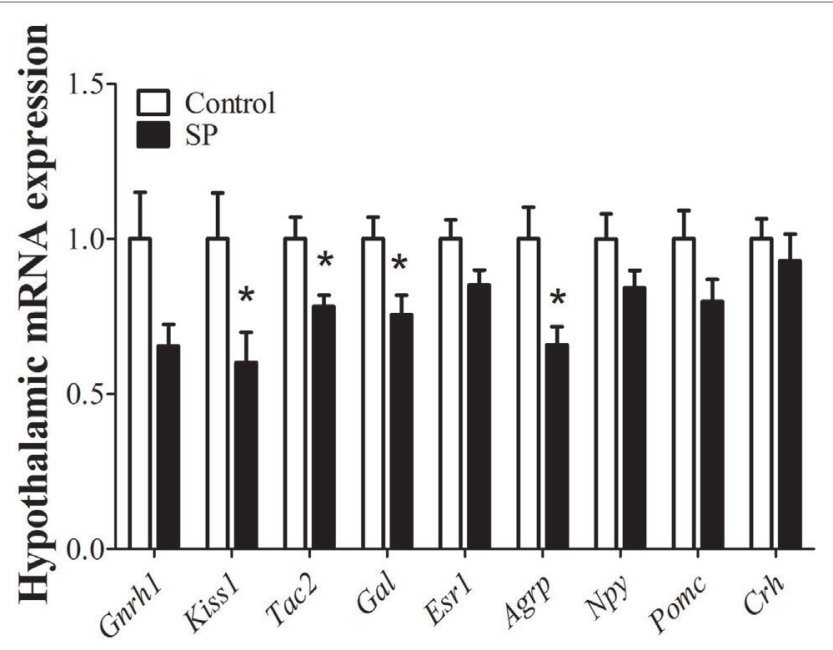

FIGURE 2 | Hypothalamic mRNA expression analysis in control animals and in females born and raised under a short-day photoperiod (SP; $n=7$ per group). ${ }^{\star} P<0.05$ vs control.

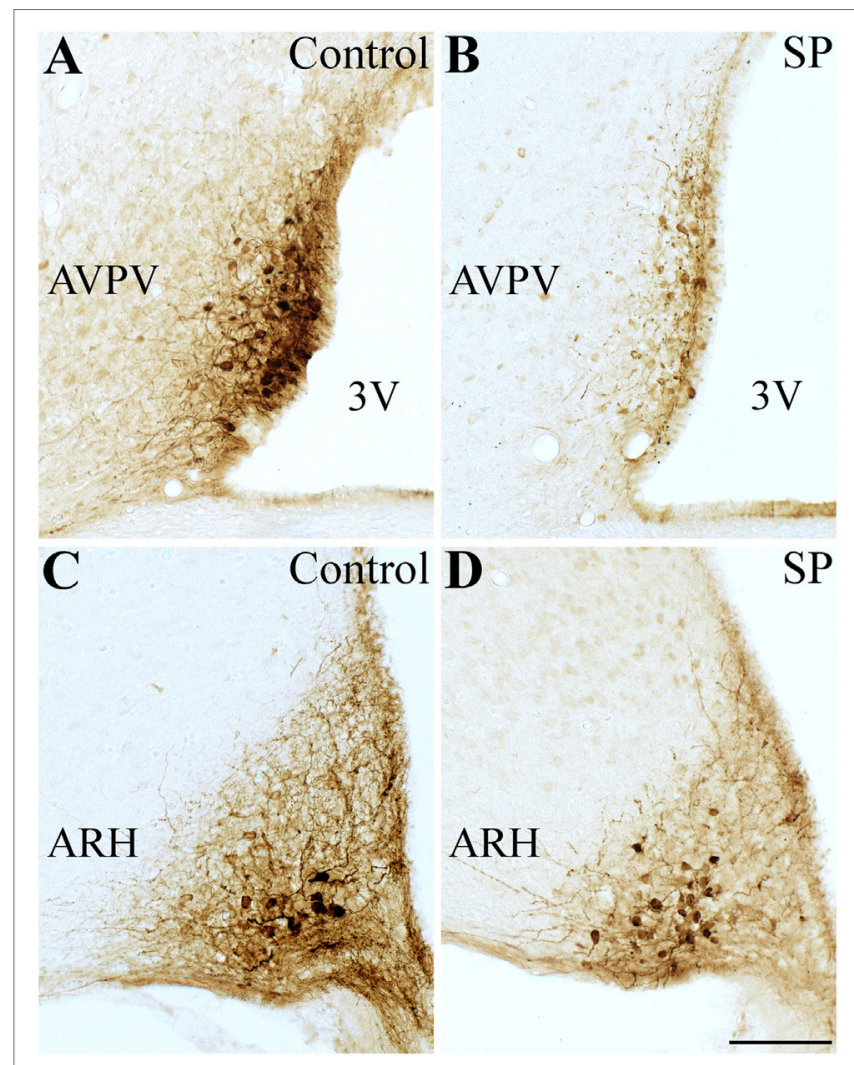

FIGURE 3 | Effects of the short-day photoperiod (SP) on kisspeptin hypothalamic expression. (A-D) Brightfield photomicrographs of mouse brain sections showing the expression of the humanized Renilla green fluorescent protein (hrGFP) in the anteroventral periventricular nucleus [AVPV $(\mathbf{A}, \mathbf{B})]$ and in the arcuate nucleus $[A R H(\mathbf{C}, \mathbf{D})] .(\mathbf{B}, \mathbf{D}) \mathrm{SP}$ led to a reduced number of Kiss1-expressing neurons in the AVPV compared to control $(\mathbf{A}, \mathbf{C})$. Abbreviation: $3 \mathrm{~V}$, third ventricle. Scale bar: $50 \mu \mathrm{m}$.

\section{Photoperiod Leads to a Reduced Number of Kiss1-expressing Neurons}

We used Kiss1-hrGFP mice to determine the number of Kiss1-expressing cells, as previously described (19). Interestingly, females raised under SP had lower number of neurons expressing hrGFP compared with control mice (Figure 3). In the AVPV/PeN, we observed a reduction of approximately $50 \%$ in the number of hrGFP cells compared with control mice (Control: $29.7 \pm 2.3$ cells; SP: $15.8 \pm 2.3$ cells; $n=4, P=0.002)$. However, the number of hrGFP cells in the ARH was similar between the groups (Control: $20.1 \pm 4.1$ cells; SP: $14.0 \pm 1.4$ cells; $n=4, P=0.2$ ). These results indicate that the delayed sexual maturation observed in SP females could be caused by lower kisspeptin expression in the AVPV/PeN.

\section{The Delayed Puberty Timing Caused by SP Depends on Changes in Body Weight}

Since nutritional status is known to affect the timing of puberty $(22,27-30)$, we next evaluated whether a protocol that increases body mass could revert the observed effects in the puberty timing of females born and raised under SP. We observed that females born under SP and raised in small litters exhibited vaginal opening at a similar age as females born under SP and raised in regular litters (Figures $4 \mathbf{A}, \mathbf{B} ; P=0.9$ ). However, the average age of the first estrus (Figures 4D,E; $P=0.004$ ) and the onset of estrous cyclicity (Figures 4G,H; $P=0.04)$ of females from small litters were significantly advanced compared to those of females from regular litters. While more than $70 \%$ of females from small litters had their first estrus by 42 days of age, approximately $30 \%$ of females from regular litters had reached the same stage of sexual maturation at that age (Figure 4D). At 42 days of age, more than $70 \%$ of females from small litters had started to cycle, compared with approximately $30 \%$ of females from regular litters under SP (Figure 4G). Although no significant differences in body weight were observed between groups at any specific stage of sexual maturation (Figures 4C,F,I), females from small litters exhibited larger body weight than females from regular litters during development (Figure 4J; $P<0.0001$ ). In addition, no significant differences were noted in the uterine mass of adult mice (Figure 4K; $P=0.7$ ).

Given that the effects on the timing of puberty were probably dependent on body weight changes, a reversal in hypothalamic mRNA expression should be expected in SP females raised in small litters. In fact, we observed that hypothalamic Kiss 1 mRNA $(P=0.04)$ and Gal mRNA expression levels $(P=0.008)$ were significantly increased in females from small litters compared with females from regular litters under SP. No significant differences were noted in Gnrh1 $(P=0.8)$, Tac2 $(P=0.5)$, Esr1 $(P=0.5)$, or $C r h$ mRNA expression $(P=0.1$, Figure 5$)$. In addition, significant increases in the hypothalamic mRNA expression levels of $\operatorname{Agrp}(P<0.0001), \operatorname{Npy}(P=0.005)$, and $\operatorname{Pomc}(P=0.03)$ were observed in females from small litters born and raised in SP (Figure 5). 

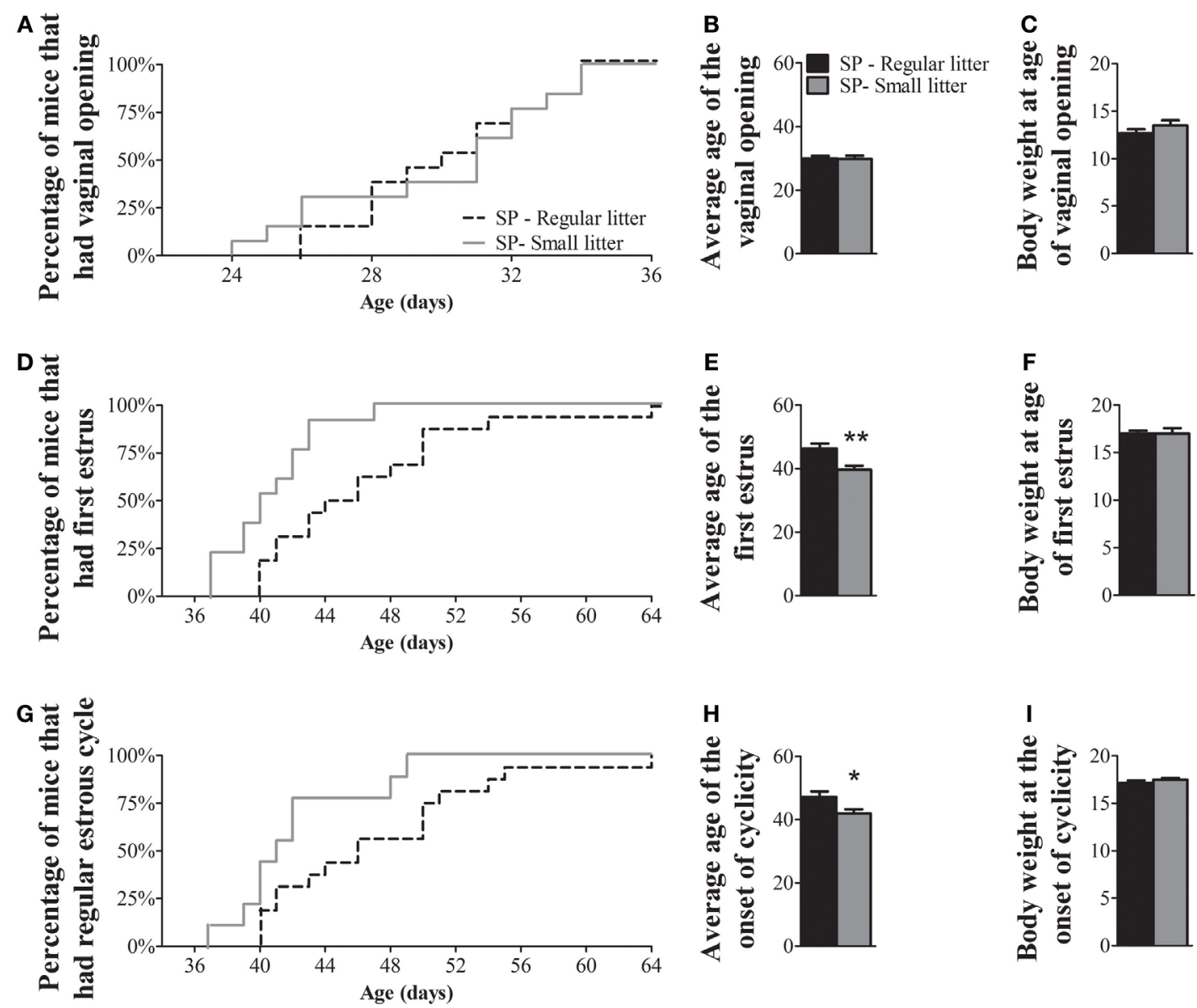

FIGURE 4 | Increased body weight advances the timing of puberty in female mice born and raised under a short-day photoperiod (SP). (A,D,G) Graphs showing the percentages of females from regular control litters compared to females from small litters that exhibited vaginal opening (A), first estrus (D), and the first occurrence of an estrous cycle of typical duration $[(\mathbf{G}) n=13 / 16$ per group]. (B,E, $\mathbf{H})$ Average time required for females to exhibit vaginal opening (B), first estrus $\mathbf{( E )}$, and the onset of estrous cyclicity $\mathbf{( H )}$. (C, $\mathbf{F}, \mathbf{I}, \mathbf{J})$. Body weight of females from regular and small litters at specific stages of sexual maturation and during development $\mathbf{( J )}$. (K) Uterine mass of adult females from regular litters and small litters $\left(n=4 / 6\right.$ per group). ${ }^{\star} P<0.05$, ${ }^{\star \star} P<0.005$ vs females from regular control litter.

\section{DISCUSSION}

In the present study, we used a SP condition to demonstrate how photoperiodic information affects the timing of puberty in female mice and whether these effects occur via kisspeptin system. Since we observed that SP also affected energy homeostasis, we also tested the hypothesis that photoperiodism may regulate the timing of sexual maturation in female mice via changes in body weight.
In seasonally breeding rodents, the effects of short-photoperiod in the reproductive system are attributed to an extended period of melatonin secretion (18). Importantly, although several reports demonstrated that most mouse strains are melatonin deficient (31-33), others have reported that some strains, such as $\mathrm{C} 57 \mathrm{BL} / 6$, are able to produce small amounts of melatonin (34, $35)$. Therefore, C57BL/6 strain has been routinely and successfully used in melatonin studies $(36,37)$. Accordingly, SP was able to cause robust changes in our mouse model, which indicates that 


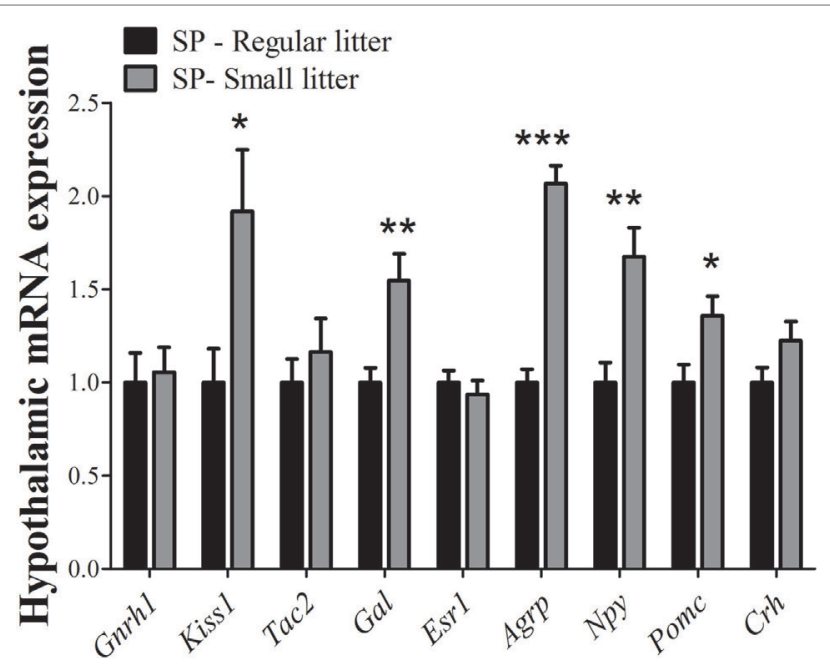

FIGURE 5 | Hypothalamic mRNA expression analysis comparing data obtained of females from regular control or small litters born and raised under a short-day photoperiod (SP, $n=7 / 9$ per group). ${ }^{\star} P<0.05$, ${ }^{\star \star} P<0.005$, ${ }^{\star \star \star} P<0.0001$ vs regular litter.

C57BL/6 mice are clearly responsive to photoperiod variations. The observed effects on sexual maturation may be time-dependent, since C57BL/6 mice are unable to mount a photoperiodic response after only 2 weeks of acclimation in SP (38).

Previous studies that evaluated the importance of photoperiod or melatonin in reproduction showed no information about body weight changes $(13,14,39)$. However, the effects of SP in reducing the body weight of seasonal rodents have been documented and these changes can be prevented by the removal of the pineal gland $(26,40,41)$. The observed effects on body weight in the present work were obtained independently of environmental conditions, such as food availability, suggesting that photoperiod directly modulates the energy balance of female mice, as previous described (11). In rats and mice, melatonin is a known metabolic factor capable of reducing fat mass and circulating leptin levels; two well-known metabolic cues that determine the timing of sexual development $(12,22$, 27-30, 42-44). Therefore, although SP could directly regulate the timing of sexual maturation, our results suggest that fat mass deposition can also be an important factor that influences the timing of puberty in female mice. To test the hypothesis that body weight gain was the most critical factor required for sexual maturation, we used a model of prepubertal overnutrition by raising mice in small litters in SP (20-22). The increased body weight of females raised in small litters and SP advanced the timing of puberty, as demonstrated by the early age of detection of first estrus and the onset of estrous cyclicity compared with females raised in regular litters and SP. Previous studies have already demonstrated that the small litter protocol is efficient in causing prepubertal overnutrition, increasing body weight and advancing markers of sexual maturation (20-22, 44).

Here, we demonstrated that, additionally to the lower body weight, mice raised in SP exhibited a significant reduction of Kiss 1 mRNA hypothalamic levels, compared to mice raised in
$12 \mathrm{~h}: 12 \mathrm{~h}$ light/dark cycle, similar to what has been described for hamsters $(13,14)$. In addition, Tac2 and Gal mRNA expression levels were also suppressed by SP in female mice. Histological experiments further determined that the decrease in Kiss 1 expression mainly depended on a reduced number of Kiss 1 expressing neurons in the AVPV/PeN, whereas the number of Kiss1-expressing cells was similar in the ARH of control and SP mice, consistent with what has been previously reported in rats (13). In contrast to our results, hamsters maintained under SP show lower Kiss1 mRNA expression in both the ARH and the AVPV/PeN (14). These differences may indicate interspecies variations. Regardless, it is important to remember that undernutrition, as induced by fasting, is sufficient to reduce Kiss $1 \mathrm{mRNA}$ expression in rats $(45,46)$, which supports the hypothesis that the observed effects of SP on the timing of puberty are dependent on energy stores. In agreement with this idea, we observed that female mice raised in small litters in SP exhibited increased Kiss 1 and Gal mRNA expression levels. In addition, SP clearly affected the expression of genes known to modulate energy balance in mice raised in both regular and small litters. Female mice born and raised under SP exhibited decreased expression of Agrp mRNA compared to mice raised in $12 \mathrm{~h}: 12 \mathrm{~h}$ light/dark cycle. Since AgRP has orexigenic effects, these changes could help to explain the leaner body weight observed in this group. On the other hand, mice from small litters and raised under SP showed significant increases in Agrp and Npy mRNA expression in the hypothalamus, indicating that the orexigenic effects of these neuropeptides could be responsible for the higher body mass gain in this group. By contrast, Pomc encodes anorexigenic neuropeptides, including $\alpha-\mathrm{MSH}$. Although hypothalamic Pomc expression normally exhibits the opposite behavior compared to Agrp, in our experiments Pomc levels varied similarly to Agrp/ Npy expression. It is possible that the changes observed in Pomc expression are an attempt to compensate for the increased Agrp/ Npy expression and, consequently, to restore energy homeostasis. Previous studies have shown that hypothalamic expression of Pomc is increased in situations that induce obesity, such as a high-fat diet or ovariectomy $(47,48)$. Altogether, these findings provide evidence that SP induces changes in body weight via hypothalamic neurocircuits that regulate energy balance. Therefore, future studies could investigate the mechanisms or factors recruited by SP to affect the expression of key neuropeptides that regulate energy homeostasis, especially in Agrp/ Npy expressing neurons. In addition, we cannot rule out the hypothesis that the results obtained were dependent on circadian time because tissue collection from mice raised in $12 \mathrm{~h}: 12 \mathrm{~h}$ light/dark and in SP were collected at different ZT. However, as demonstrated previously (49), sacrifice ZT did not affect gene expression of peptides related to the reproductive axis since all females were in diestrus. Considering that there is evidence in humans that reproductive dysfunctions, such as precocious puberty or functional hypogonadotropic hypogonadism, may be followed by significant variations in melatonin levels (50-53), future studies should determine whether such disorders were accompanied by changes in energy homeostasis.

In summary, our results demonstrate that SP affects the timing of puberty in female mice. The effects in sexual maturation are 
followed by a decrease in body weight gain during development and by a lower Kiss1 mRNA expression in the hypothalamus. Reestablishment of body weight gain in SP conditions by reduction of litter size leads to advanced timing of puberty and increased Kiss1 mRNA levels, indicating that the effects of SP in the HPG axis are likely secondary to changes in body weight gain.

\section{ETHICS STATEMENT}

All experiments and procedures were performed in accordance with the guidelines established by the National Institute of Health's Guide for the Care and Use of Laboratory Animals and were approved by the Committee on the Care and Use of Laboratory Animals of the Institute of Biomedical Sciences, University of São Paulo.

\section{REFERENCES}

1. Hendrickson AE, Wagoner N, Cowan WM. An autoradiographic and electron microscopic study of retino-hypothalamic connections. Z Zellforsch Mikrosk Anat (1972) 135(1):1-26. doi:10.1007/bf00307084

2. Moore RY, Lenn NJ. A retinohypothalamic projection in the rat. J Comp Neurol (1972) 146(1):1-14. doi:10.1002/cne.901460102

3. Brown-Grant K, Raisman G. Abnormalities in reproductive function associated with the destruction of the suprachiasmatic nuclei in female rats. Proc R Soc Lond B Biol Sci (1977) 198(1132):279-96. doi:10.1098/rspb.1977.0098

4. Wiegand SJ, Terasawa E, Bridson WE, Goy RW. Effects of discrete lesions of preoptic and suprachiasmatic structures in the female rat. Alterations in the feedback regulation of gonadotropin secretion. Neuroendocrinology (1980) 31(2):147-57. doi:10.1159/000123066

5. Prata Lima MF, Baracat EC, Simoes MJ. Effects of melatonin on the ovarian response to pinealectomy or continuous light in female rats: similarity with polycystic ovary syndrome. Braz J Med Biol Res (2004) 37(7):987-95. doi:10.1590/S0100-879X2004000700007

6. Huether G. The contribution of extrapineal sites of melatonin synthesis to circulating melatonin levels in higher vertebrates. Experientia (1993) 49(8):665-70. doi:10.1007/bf01923948

7. Goldman BD. Mammalian photoperiodic system: formal properties and neuroendocrine mechanisms of photoperiodic time measurement. J Biol Rhythms (2001) 16(4):283-301. doi:10.1177/074873001129001980

8. Chu EW, Wurtman RJ, Axelrod J. An inhibitory effect of melatonin on the estrous phase of the estrous cycle of the rodent. Endocrinology (1964) 75:238-42. doi:10.1210/endo-75-2-238

9. Ying SY, Greep RO. Inhibition of ovulation by melatonin in the cyclic rat. Endocrinology (1973) 92(1):333-5. doi:10.1210/endo-92-1-333

10. Nelson RJ. Photoperiodic responsiveness in house mice. Physiol Behav (1990) 48(3):403-8. doi:10.1016/0031-9384(90)90335-2

11. Kasahara T, Abe K, Mekada K, Yoshiki A, Kato T. Genetic variation of melatonin productivity in laboratory mice under domestication. Proc Natl Acad Sci US A (2010) 107(14):6412-7. doi:10.1073/pnas.0914399107

12. de Oliveira AC, Andreotti S, Farias Tda S, Torres-Leal FL, de Proenca AR, Campana $\mathrm{AB}$, et al. Metabolic disorders and adipose tissue insulin responsiveness in neonatally STZ-induced diabetic rats are improved by long-term melatonin treatment. Endocrinology (2012) 153(5):2178-88. doi:10.1210/ en.2011-1675

13. Revel FG, Saboureau M, Masson-Pevet M, Pevet P, Mikkelsen JD, Simonneaux V. Kisspeptin mediates the photoperiodic control of reproduction in hamsters. Curr Biol (2006) 16(17):1730-5. doi:10.1016/j.cub.2006.07.025

14. Ansel L, Bolborea M, Bentsen AH, Klosen P, Mikkelsen JD, Simonneaux V. Differential regulation of kiss1 expression by melatonin and gonadal hormones in male and female Syrian hamsters. J Biol Rhythms (2010) 25(2):81-91. doi:10.1177/0748730410361918

15. Han SK, Gottsch ML, Lee KJ, Popa SM, Smith JT, Jakawich SK, et al. Activation of gonadotropin-releasing hormone neurons by kisspeptin as a neuroendocrine switch for the onset of puberty. J Neurosci (2005) 25(49):11349-56. doi:10.1523/JNEUROSCI.3328-05.2005

\section{AUTHOR CONTRIBUTIONS}

TMB, MAS, DCB and HCFN performed the experiments. RF, JDJ and JCN designed the experiments. RF coordinated the studies and wrote the paper.

\section{FUNDING}

This work was supported by São Paulo Research Foundation (FAPESP; grant \# 2012/12202-4 to RF, grant \#2015/ 10992-6 to JD; 2015/26190-6 to DB) and Coordenação de Aperfeiçoamento de Pessoal de Nível Superior (CAPES; fellowship to TB and MS).

16. d'Anglemont de Tassigny X, Fagg LA, Carlton MB, Colledge WH. Kisspeptin can stimulate gonadotropin-releasing hormone $(\mathrm{GnRH})$ release by a direct action at GnRH nerve terminals. Endocrinology (2008) 149(8):3926-32. doi:10.1210/en.2007-1487

17. Gottsch ML, Cunningham MJ, Smith JT, Popa SM, Acohido BV, Crowley WF, et al. A role for kisspeptins in the regulation of gonadotropin secretion in the mouse. Endocrinology (2004) 145(9):4073-7. doi:10.1210/en. 2004-0431

18. Revel FG, Ansel L, Klosen P, Saboureau M, Pevet P, Mikkelsen JD, et al. Kisspeptin: a key link to seasonal breeding. Rev Endocr Metab Disord (2007) 8(1):57-65. doi:10.1007/s11154-007-9031-7

19. Cravo RM, Frazao R, Perello M, Osborne-Lawrence S, Williams KW, Zigman JM, et al. Leptin signaling in Kiss1 neurons arises after pubertal development. PLoS One (2013) 8(3):e58698. doi:10.1371/journal.pone.0058698

20. Plagemann A, Harder T, Rake A, Waas T, Melchior K, Ziska T, et al. Observations on the orexigenic hypothalamic neuropeptide Y-system in neonatally overfed weanling rats. J Neuroendocrinol (1999) 11(7):541-6. doi:10.1046/j.1365-2826.1999.00357.x

21. Rodrigues AL, de Moura EG, Passos MC, Trevenzoli IH, da Conceicao EP, Bonono IT, et al. Postnatal early overfeeding induces hypothalamic higher SOCS3 expression and lower STAT3 activity in adult rats. J Nutr Biochem (2011) 22(2):109-17. doi:10.1016/j.jnutbio.2009.11.013

22. Bohlen TM, Silveira MA, Zampieri TT, Frazao R, Donato J Jr. Fatness rather than leptin sensitivity determines the timing of puberty in female mice. $\mathrm{Mol}$ Cell Endocrinol (2016) 423:11-21. doi:10.1016/j.mce.2015.12.022

23. Nelson JF, Karelus K, Felicio LS, Johnson TE. Genetic influences on the timing of puberty in mice. Biol Reprod (1990) 42(4):649-55. doi:10.1095/ biolreprod42.4.649

24. Franklin KBJ, Paxinos G. The Mouse Brain in Stereotaxic Coordinates. Oxford: Elsevier Global Rights Department (2008).

25. Hoffmann K. Effects of short photoperiods on puberty, growth and moult in the Djungarian hamster (Phodopus sungorus). J Reprod Fertil (1978) 54(1):29-35. doi:10.1530/jrf.0.0540029

26. Ebling FJ, Foster DL. Pineal melatonin rhythms and the timing of puberty in mammals. Experientia (1989) 45(10):946-54. doi:10.1007/BF01953052

27. Kaplowitz PB, Slora EJ, Wasserman RC, Pedlow SE, Herman-Giddens ME. Earlier onset of puberty in girls: relation to increased body mass index and race. Pediatrics (2001) 108(2):347-53. doi:10.1542/peds.108.2.347

28. Dunger DB, Ahmed ML, Ong KK. Early and late weight gain and the timing of puberty. Mol Cell Endocrinol (2006) 254-255:140-5. doi:10.1016/j. mce.2006.04.003

29. Martos-Moreno GA, Chowen JA, Argente J. Metabolic signals in human puberty: effects of over and undernutrition. Mol Cell Endocrinol (2010) 324(1-2):70-81. doi:10.1016/j.mce.2009.12.017

30. Roa J, Tena-Sempere M. Connecting metabolism and reproduction: roles of central energy sensors and key molecular mediators. Mol Cell Endocrinol (2014) 397(1-2):4-14. doi:10.1016/j.mce.2014.09.027

31. Ebihara S, Marks T, Hudson DJ, Menaker M. Genetic control of melatonin synthesis in the pineal gland of the mouse. Science (1986) 231(4737):491-3. doi:10.1126/science.3941912 
32. Goto M, Oshima I, Tomita T, Ebihara S. Melatonin content of the pineal gland in different mouse strains. J Pineal Res (1989) 7(2):195-204. doi:10.1111/ j.1600-079X.1989.tb00667.x

33. Roseboom PH, Namboodiri MAA, Zimonjic DB, Popescu NC, Rodriguez I, Gastel JA, et al. Natural melatonin 'knockdown' in C57BL/6J mice: rare mechanism truncates serotonin N-acetyltransferase. Mol Brain Res (1998) 63(1):189-97. doi:10.1016/s0169-328x(98)00273-3

34. Conti A, Maestroni GJ. HPLC validation of a circadian melatonin rhythm in the pineal gland of inbred mice. J Pineal Res (1996) 20(3):138-44. doi:10.1111/ j.1600-079X.1996.tb00249.x

35. Vivien-Roels B, Malan A, Rettori MC, Delagrange P, Jeanniot JP, Pevet P. Daily variations in pineal melatonin concentrations in inbred and outbred mice. J Biol Rhythms (1998) 13(5):403-9. doi:10.1177/074873098129000228

36. Dubocovich ML, Hudson RL, Sumaya IC, Masana MI, Manna E. Effect of MT1 melatonin receptor deletion on melatonin-mediated phase shift of circadian rhythms in the C57BL/6 mouse. J Pineal Res (2005) 39(2):113-20. doi:10.1111/j.1600-079X.2005.00230.x

37. Adamah-Biassi EB, Hudson RL, Dubocovich ML. Genetic deletion of MT1 melatonin receptors alters spontaneous behavioral rhythms in male and female C57BL/6 mice. Horm Behav (2014) 66(4):619-27. doi:10.1016/j. yhbeh.2014.08.012

38. Ono H, Hoshino Y, Yasuo S, Watanabe M, Nakane Y, Murai A, et al. Involvement of thyrotropin in photoperiodic signal transduction in mice. Proc Natl Acad Sci U S A (2008) 105(47):18238-42. doi:10.1073/pnas.0808952105

39. Ancel C, Bentsen AH, Sébert ME, Tena-Sempere M, Mikkelsen JD, Simonneaux V. Stimulatory effect of RFRP-3 on the gonadotrophic axis in the male syrian hamster: the exception proves the rule. Endocrinology (2012) 153(3):1352-63. doi:10.1210/en.2011-1622

40. Hoffman RA, Reiter RJ. Pineal gland: influence on gonads of male hamsters. Science (1965) 148(3677):1609-11. doi:10.1126/science.148.3677.1609

41. Vitale PM, Darrow JM, Duncan MJ, Shustak CA, Goldman BD. Effects of photoperiod, pinealectomy and castration on body weight and daily torpor in Djungarian hamsters (Phodopus sungorus). J Endocrinol (1985) 106(3):367-75. doi:10.1677/joe.0.1060367

42. Ahima RS, Dushay J, Flier SN, Prabakaran D, Flier JS. Leptin accelerates the onset of puberty in normal female mice. J Clin Invest (1997) 99(3):391-5. doi:10.1172/JCI119172

43. Rasmussen DD, Boldt BM, Wilkinson CW, Yellon SM, Matsumoto AM. Daily melatonin administration at middle age suppresses male rat visceral fat, plasma leptin, and plasma insulin to youthful levels. Endocrinology (1999) 140(2):1009-12. doi:10.1210/endo.140.2.6674

44. Sanchez-Garrido MA, Castellano JM, Ruiz-Pino F, Garcia-Galiano D, Manfredi-Lozano M, Leon S, et al. Metabolic programming of puberty: sexually dimorphic responses to early nutritional challenges. Endocrinology (2013) 154(9):3387-400. doi:10.1210/en.2012-2157

45. Castellano JM, Navarro VM, Fernandez-Fernandez R, Nogueiras R, Tovar S, Roa J, et al. Changes in hypothalamic KiSS-1 system and restoration of pubertal activation of the reproductive axis by kisspeptin in undernutrition. Endocrinology (2005) 146(9):3917-25. doi:10.1210/en.2005-0337

46. Matsuzaki T, Iwasa T, Kinouchi R, Yoshida S, Murakami M, Gereltsetseg G, et al. Fasting reduces the kiss1 mRNA levels in the caudal hypothalamus of gonadally intact adult female rats. Endocr J (2011) 58(11):1003-12. doi:10.1507/ endocrj.K11E-131

47. Ziotopoulou M, Mantzoros CS, Hileman SM, Flier JS. Differential expression of hypothalamic neuropeptides in the early phase of diet-induced obesity in mice. Am J Physiol Endocrinol Metab (2000) 279(4):E838-45. doi:10.1152/ ajpendo.2000.279.4.E838

48. da Silva RP, Zampieri TT, Pedroso JA, Nagaishi VS, Ramos-Lobo AM, Furigo IC, et al. Leptin resistance is not the primary cause of weight gain associated with reduced sex hormone levels in female mice. Endocrinology (2014) 155(11):4226-36. doi:10.1210/en.2014-1276

49. Robertson JL, Clifton DK, de la Iglesia HO, Steiner RA, Kauffman AS. Circadian regulation of Kiss1 neurons: implications for timing the preovulatory gonadotropin-releasing hormone/luteinizing hormone surge. Endocrinology (2009) 150(8):3664-71. doi:10.1210/en.2009-0247

50. Berga SL, Mortola JF, Yen SS. Amplification of nocturnal melatonin secretion in women with functional hypothalamic amenorrhea. J Clin Endocrinol Metab (1988) 66(1):242-4. doi:10.1210/jcem-66-1-242

51. Brzezinski A, Lynch HJ, Seibel MM, Deng MH, Nader TM, Wurtman RJ. The circadian rhythm of plasma melatonin during the normal menstrual cycle and in amenorrheic women. J Clin Endocrinol Metab (1988) 66(5):891-5. doi:10.1210/jcem-66-5-891

52. Laughlin GA, Loucks AB, Yen SS. Marked augmentation of nocturnal melatonin secretion in amenorrheic athletes, but not in cycling athletes: unaltered by opioidergic or dopaminergic blockade. J Clin Endocrinol Metab (1991) 73(6):1321-6. doi:10.1210/jcem-73-6-1321

53. Waldhauser F, Boepple PA, Schemper M, Mansfield MJ, Crowley WF Jr. Serum melatonin in central precocious puberty is lower than in age-matched prepubertal children. J Clin Endocrinol Metab (1991) 73(4):793-6. doi:10.1210/ jcem-73-4-793

Conflict of Interest Statement: The authors declare that the research was conducted in the absence of any commercial or financial relationships that could be construed as a potential conflict of interest.

Copyright (C) 2018 Bohlen, Silveira, Buonfiglio, Ferreira-Neto, Cipolla-Neto, Donato and Frazao. This is an open-access article distributed under the terms of the Creative Commons Attribution License (CC BY). The use, distribution or reproduction in other forums is permitted, provided the original author(s) and the copyright owner are credited and that the original publication in this journal is cited, in accordance with accepted academic practice. No use, distribution or reproduction is permitted which does not comply with these terms. 